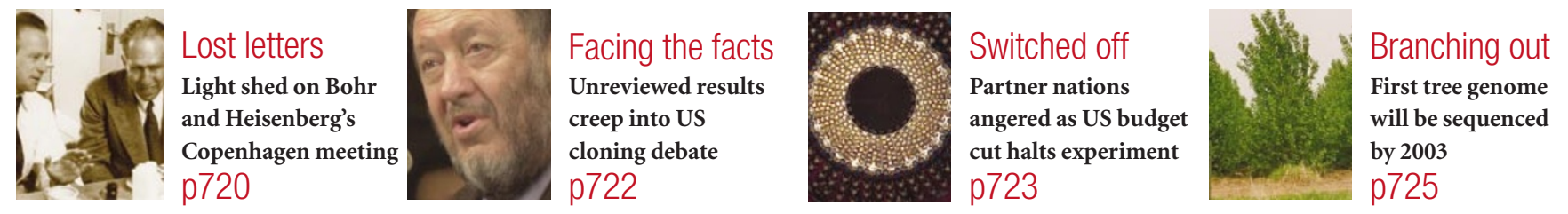

\title{
Biodefence boost leaves experts worried over laboratory safety
}

Jonathan Knight, San Francisco

A massive infusion of cash for biodefence research, proposed with much fanfare in President George W. Bush's 2003 budget request on 4 February, has a number of US scientists and bioweapons experts on edge.

They worry that the new spending, which includes a sevenfold increase in biodefence funding for the National Institutes of Health (NIH), will stimulate the proliferation of labs that handle dangerous pathogens, and raise the risk of an accidental or deliberate release.

Nearly all of the NIH money for biodefence is to be administered by the National Institute of Allergy and Infectious Diseases (NIAID), whose budget would grow next year by almost $60 \%$, to $\$ 4$ billion, under the Bush proposal. It includes $\$ 430$ million in new funds to build secure containment facilities for hazardous microbes, and \$533 million for drug and vaccine research. The NIAID would also get $\$ 441$ million, a sixfold increase, for basic research into the biology of bioterror agents.

But the prospect of dozens of labs across the country handling pathogens such as those that cause anthrax and tularaemia is nothing short of terrifying, says Richard Ebright, a molecular biologist at Rutgers University in Piscataway, New Jersey.

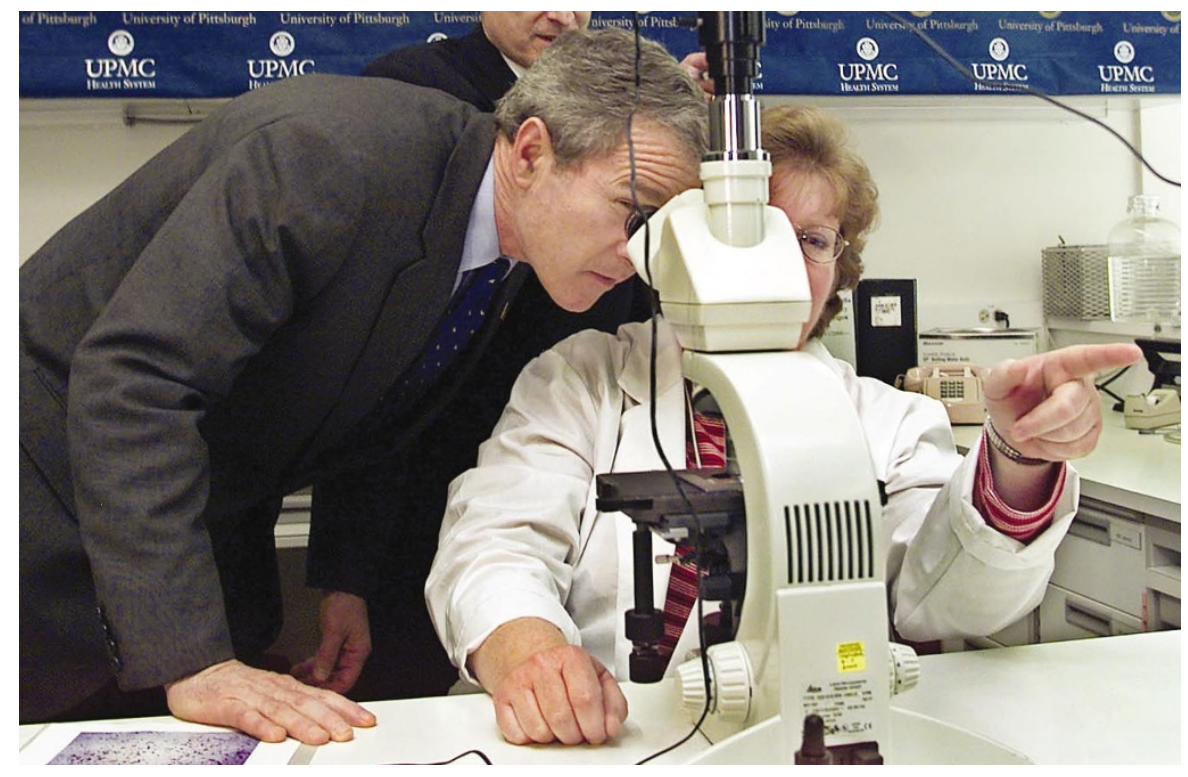

The bigger picture: President Bush's crusade against bioterrorism has provoked concern among biodefence experts that the chances of an accidental or deliberate pathogen release may be increased.

Ebright says he developed an intense interest in biodefence issues after the anthrax attacks on the United States last October were launched from his state. He argues that although detection techniques are critical for good biodefence, understanding the basic biology of the pathogens is not. "From a security perspective, we would do better to have much more restricted access and less information," he says.

Officials at the NIAID have defended the increase from criticisms that it might cause

\section{American Red Cross turns its back on stem-cell grant}

Jonathan Knight, San Francisco

The American Red Cross has refused to accept the first federal grant to be awarded in the United States for research using human embryonic stem cells.

The award was a $\$ \mathbf{5 0 , 0 0 0}$ supplement to an existing five-year grant for leukaemia research using mouse embryonic stem cells, given to a team led by Robert Hawley of the Red Cross's Holland Laboratories in Rockville, Maryland.

After the National Institutes of Health announced the award on 8 February, American Red Cross chief scientific officer Jerry Squires issued a statement saying that the organization had revised its research priorities and would decline the money.

This explanation met with deep scepticism from scientists familiar with using stem cells. To refuse a grant already awarded is extremely rare, says Lawrence Goldstein, a cell biologist at the University of California, San Diego, who uses mouse embryonic stem cells. "Why, after going through all the trouble to apply, they would turn around and refuse the money is beyond me," he says.

Hawley's five-year grant, which lasts until 2006, is to study genes involved in the differentiation of mouse blood precursor cells. According to Goldstein, confirming the results in human cells would be a logical extension of such work. Hawley did not respond to a request for an interview.

Several researchers speculated that the American Red Cross - still smarting from a public row over its distribution of funds gathered after the 11 September tragedy, and the subsequent departure of its president, Bernadine Healy — wanted to avoid being the first to take funds for research using human embryonic stem cells. "Maybe they just didn't want one more controversy," says Sean Tipton, a spokesman for the American Society for Reproductive Medicine. 


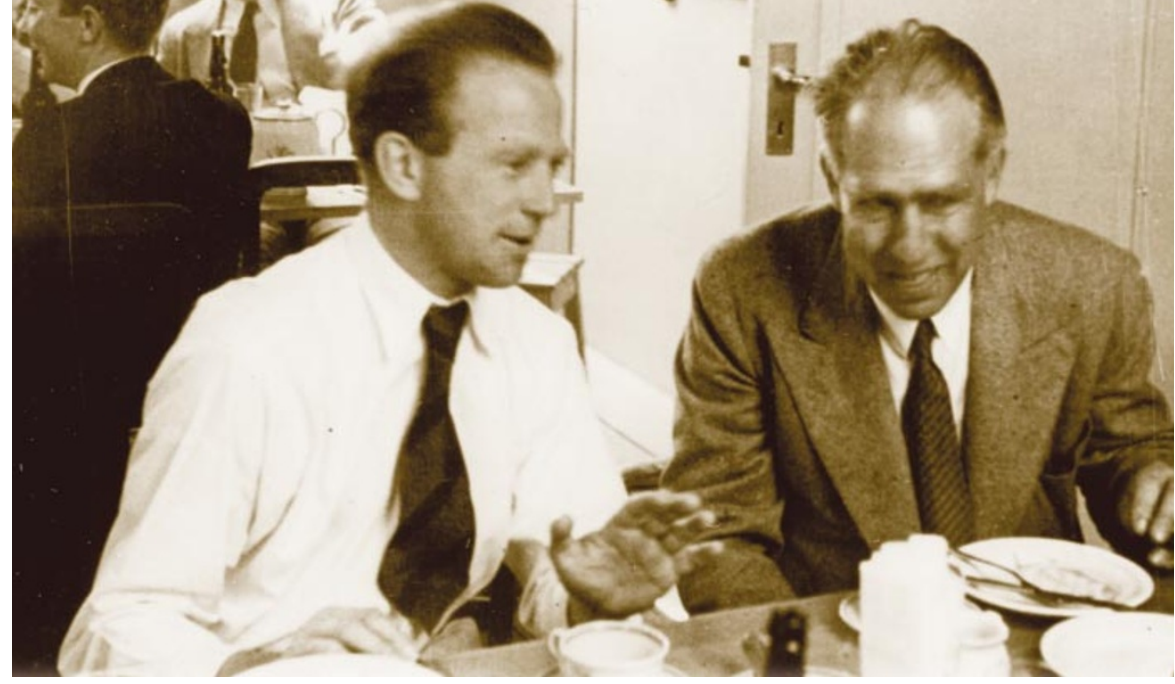

handling bioterror agents shoots up.

But security may not be of equal concern for all hazardous biological agents, argues Steven Block, a biophysicist at Stanford University in California and a member of the JASON group, which advises the government on technical issues related to defence. Whereas the smallpox virus may be hard to come by, he points out, deadly microbes such as Escherichia coli O157:H7, which can contaminate food, the bacterium Francisella tularensis, responsible for tularaemia, which flared up two years ago in Kosovo, and even the bacterium that causes anthrax, Bacillus anthracis, can be readily obtained from nature.

This distinction may soon be enshrined in law. A bill sponsored by Senators Edward Kennedy (Democrat, Massachusetts) and Bill Frist (Republican, Tennessee) instructs the health department to work with scientists in drawing up a new list of biological agents that should be subject to tight regulation. Ron Atlas, president-elect of the American Society for Microbiology, says he would hope for a hierarchy of security requirements that would take the varying risk of different agents into account.

Block and others point out that most biological agents pose only a limited threat without the technology to turn them into weapons them. But research into this would also expand under the Bush budget plan, which includes $\$ 600$ million in new funding related to bioterrorism at the Department of Defense. Part of this would fund studies of "how potential bioterrorism pathogens may be weaponized, transported, and disseminated", according to a budget fact sheet distributed by the White House.

From an international perspective, the Bush biodefence plan is part of a worldwide trend towards greater funding of biodefence research, says Jean Pascal Zanders of the Stockholm International Peace Research Institute. At least 12 countries, including Sweden, already have high-containment facilities, known as biosafety level 4 labs, and several others are expected to announce plans this year to build their own, Zanders says. "We could get a sort of arms race on the defensive side," he says, "and it might spill over into an offensive one."

Happier times: Bohr (right), who regarded Heisenberg almost as a son, later wrote him angry letters.

\section{Physicist's letters reveal clues to bitter wartime rift}

\section{Alison Abbott, Munich}

Unsent letters written by Danish physicist Niels Bohr to his German protégé Werner Heisenberg saw the light of day for the first time on 6 February. But the long-awaited publication has failed to solve the mystery of what happened during their unhappy meeting in Nazi-occupied Copenhagen.

Heisenberg, who headed Germany's unsuccessful attempt to produce a nuclear bomb, visited Bohr in September 1941 with a colleague, Carl Friedrich von Weizsäcker, on a cultural-exchange mission to Copenhagen.

Heisenberg and Bohr went for a walk together, during which Heisenberg brought up the subject of the German nuclear-bomb programme. There is no consensus as to what exactly was said, or what Heisenberg's motive for the visit had been - whether he was trying to recruit Bohr to the German programme, trying to find out how far the Allies had progressed in their attempts to build an atomic bomb, or taking the first steps towards a moratorium against nuclear weapons. All that is known is that the incident caused a deep rift between them. The mystery formed the basis of Michael Frayn's successful play Copenhagen.

The newly published letters and notes were written between 1957 and 1962. After the war, Heisenberg claimed that he had wanted to discuss with Bohr the prospect of a worldwide moratorium on bomb development programmes, and moreover that he had deceived the Nazi regime into believing that a bomb was not technically possible.

But in one letter, Bohr says he remembered Heisenberg telling him "everything was being done in Germany to develop atomic weapons" and that Heisenberg "had spent the last two years working more or less exclusively on such preparations". In another, Bohr writes: "It is therefore quite incomprehensible to me that you should think that you hinted to me that German physicists would do all they could to prevent such an application of atomic science."

Immediately after reading the letters, von Weizsäcker, whose brother Richard was the German president in 1984-94, told the German Press Agency that Bohr's memories "contained deep errors". In an interview with the Munich newspaper Süddeutsche Zeitung, he said that Heisenberg had indeed been on a peace mission to promote a bomb moratorium, albeit prompted partly by selfinterest. Because Germany had given up its own programme, Heisenberg and von Weizsäcker wanted the Allies to do the same, "so that a bomb wouldn't fall on us".

Very few of the facts and viewpoints put forward are totally new to historians, but Finn Aaserud, director of the Niels Bohr Archive in Copenhagen, points out that they indicate the depth of agitation of the scientists involved. "Bohr clearly worried very intensely about it — he had, after all, considered Heisenberg as a sort of son." Thomas Powers, who wrote Heisenberg's War: The Secret History of the German Bomb, the book on which Copenhagen was based, agrees. "For the first time we have a clearer insight into what made Bohr so angry," he says.

Aaserud also notes that Bohr's letters were written during the cold war, many years after the meeting, and that seeds of doubt about Heisenberg's motivation could have been planted by the questions asked him by intelligence services and historians.

Helmut Rechenberg, head of the Heisenberg Archive in Munich, and one of Heisenberg's past pupils, comments that the letters show how much Bohr wanted to discuss with Heisenberg the meeting that disrupted their relationship. "And that's a pity, because Heisenberg told me, and others, that he wanted very much to discuss it with Bohr," says Rechenberg. Bohr's death in 1962 made this impossible.

t w w w.nbi.dk/ NBA/ papers/introduction.htm 